SŁAWOMIR Dorocki

Uniwersytet Pedagogiczny, Kraków

\title{
Wpływ kryzysu gospodarczego na przemiany struktur regionalnych Francji
}

Powszechnie uznaje się, że kryzys finansowy, którego symbolicznym początkiem było bankructwo banku Lehman Brothers we wrześniu 2008 r., w pierwszej kolejności uderzył w kraje najbardziej rozwinięte (Misbah, Marelli, Signorelli 2010, s. 5). Postępująca recesja gospodarcza z czasem objęła swym zasięgiem wszystkie sektory gospodarki światowej, oddziałując w coraz większym stopniu na krajowe rynki pracy. Jednym z regionów świata, w którym skutki kryzysu finansowego wyraźnie wpłynęły na rynek pracy, jest Europa. Według danych Eurostatu od początku kryzysu zatrudnienie w UE zmalało o ponad $4 \mathrm{mln}$, podczas gdy na całym świecie spadek ten wyniósł ok. $20 \mathrm{mln}$.

Jak podaje sprawozdanie Komisji UE „Zatrudnienie w Europie” za rok 2009, po wieloletnim okresie wysokiego wzrostu gospodarczego i intensywnego tworzenia miejsc pracy kryzys światowy, ogarniając kolejne przedsiębiorstwa, miejsca pracy i gospodarstwa domowe, wywiera negatywny wpływ na możliwości zarobkowe i perspektywy obywateli UE. Powszechnym zjawiskiem w państwach europejskich stało się zatem odwrócenie tendencji na rynku pracy, przejawiające się spadkiem miejsc pracy i wzrostem bezrobocia. Największy spadek miejsc pracy nastąpił w krajach najbardziej rozwiniętych gospodarczo, które to niejednokrotnie dotychczas charakteryzowały się wysokim tempem wzrostu zatrudnienia na tle innych państw europejskich. Według analiz europejskich instytucji spadek zatrudnienia w Europie był niemal dwa razy wyższy w krajach rozwiniętych niż w krajach rozwijających się. W krajach rozwijających się kryzys najbardziej dotknął branże ukierunkowane na eksport oraz w mniejszym stopniu rolnictwo. Natomiast w krajach rozwiniętych kryzys dotknął głównie sektory przemysłu oraz handlu. Zwolnienia w budownictwie dotyczyły w podobnym stopniu różnych regionów zarówno krajów rozwiniętych, jak i rozwijających się (Nistorescu, Ploscaru 2010).

Jak podaje Euronews z kwietnia 2010 r., powołując się na Międzynarodową Organizację Pracy, powrót rynku pracy do stanu sprzed kryzysu zajmie jeszcze wiele czasu, lecz każde ożywienie gospodarcze musi przełożyć się na wzrost liczby miejsc pracy. Ekonomiści zauważają, że w wyniku kryzysu gospodarczego i różnic w tempie jego wpływu na gospodarkę poszczególnych państw w ostatnich latach zmalała przepaść pomiędzy bogatymi krajami a tymi słabiej rozwiniętymi.

Na podstawie powyższych przesłanek w artykule podjęto próbę przełożenia prawidłowości makroekonomicznych na układ regionalny Francji. Dokonano studiów nad zagadnie- 
niem regionalnego zróżnicowania wielkości spadku zatrudnienia ${ }^{1}$ według typów pozarolniczej działalności gospodarczej. Jako przedmiot badań przyjęto zatrudnienie w przemyśle, usługach, handlu i budownictwie. Następnie podjęto analizę związku pomiędzy spadkiem zatrudnienia a poziomem rozwoju gospodarczego. Analiza owa została dokonana w oparciu o wielkość wzrostu zatrudnienia i wielkości PKB. Na koniec podjęto próbę odpowiedzi na pytanie, czy w okresie kryzysu zmalała ekonomiczna przepaść pomiędzy regionami Francji. Jako wyznacznik poziomu rozwoju gospodarczego, pomimo wielu zaostrzeń co do poprawności jego stosowania, przyjęto wielkość PKB, ze względu na jego ogólność.

W artykule wykorzystano dane statystyczne francuskiego Narodowego Instytutu Statystyki i Badań Ekonomicznych (Institut National de la Statistique et des Études Économiques, INSEE).

\section{ZMIANY ZATRUDNIENIA WE FRANCJI}

Recesja gospodarcza wywołana kryzysem finansowym wpłynęła niekorzystnie na lokalne gospodarki i rynek pracy. W przypadku Francji potwierdza się teza o odwróceniu tendencji na rynku pracy. Analizując kwartalną zmianę wielkości zatrudnienia (ryc. 1), można zauważyć, że po okresie wyraźnego wzrostu trwającego od początku 2005 r., nastąpił spadek trwający od drugiego kwartału 2008 r. do końca 2009 r. W okresie półtora roku zatrudnienie spadło o ok. 580 tys. osób, czyli o ok. 3,5\% stanu początkowego i powróciło do liczebności z początku 2005 r. Spadek zatrudnienia wyniósł w tym okresie ok. 310 os./rok i był szybszy od jego wcześniejszego wzrostu, który wnosił 210 os./rok.

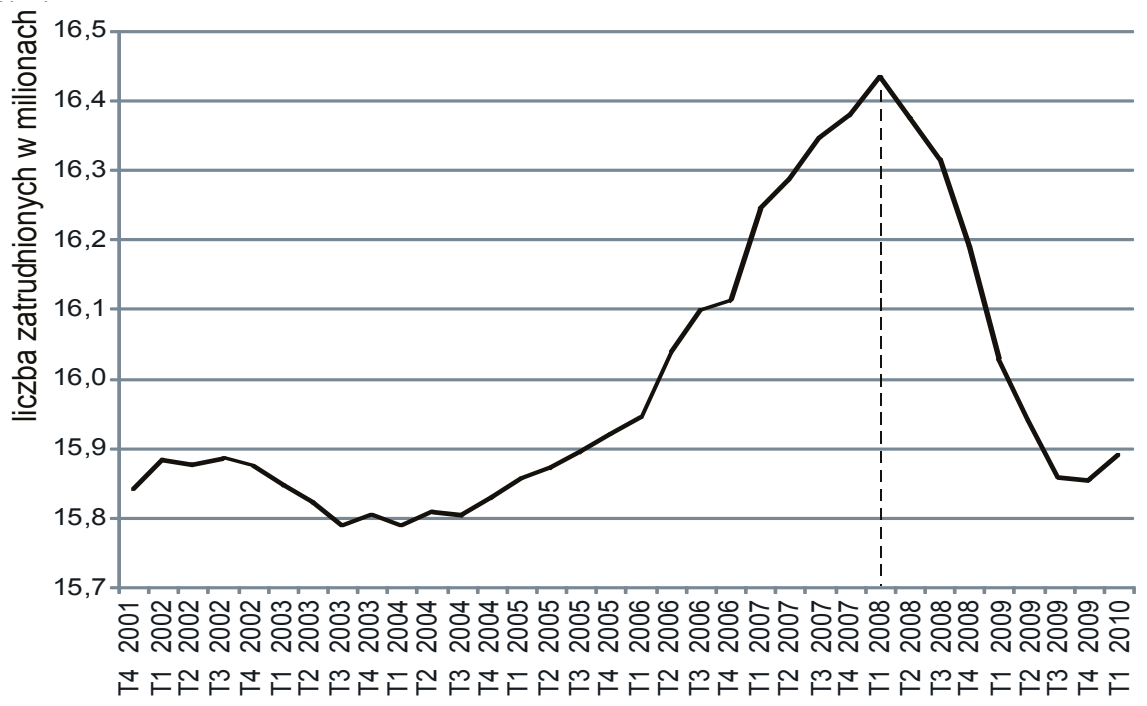

Ryc. 1. Wielkość zatrudnienia we Francji w okresie od IV kw. 2001 r. do I kw. 2010 r.

Źródło: opracowanie własne na podstawie danych INSEE

${ }^{1}$ Według statystyki francuskiej do zatrudnionych zaliczono wszystkich ludzi, którzy pracują na podstawie umowy o pracę i otrzymują w zamian wynagrodzenie lub ekwiwalent wynagrodzenia. 
W ujęciu regionalnym największy średniokwartalny spadek zatrudnienia w okresie kryzysu finansowego (2008-2009) nastąpił w północnej części Francji, największy spadek zatrudnienia odnotowano w regionach północno-zachodnich, tj. Franche-Comté i w Lotaryngii oraz w Burgundii, Pikardii i Szampanii (ryc. 2). Spośród regionów północnych wyróżnia się region paryski, charakteryzujący się o połowę mniejszym spadkiem zatrudnienia niż regiony sąsiednie. Najmniejszy spadek wystapił w położonych za Masywem Centralnym południowych regionach Francji, od Akwitanii nad Atlantykiem po region Prowansja-Alpy-Lazurowe Wybrzeże. Jedynym regionem, w którym nie nastąpił spadek zatrudnienia, była Korsyka.
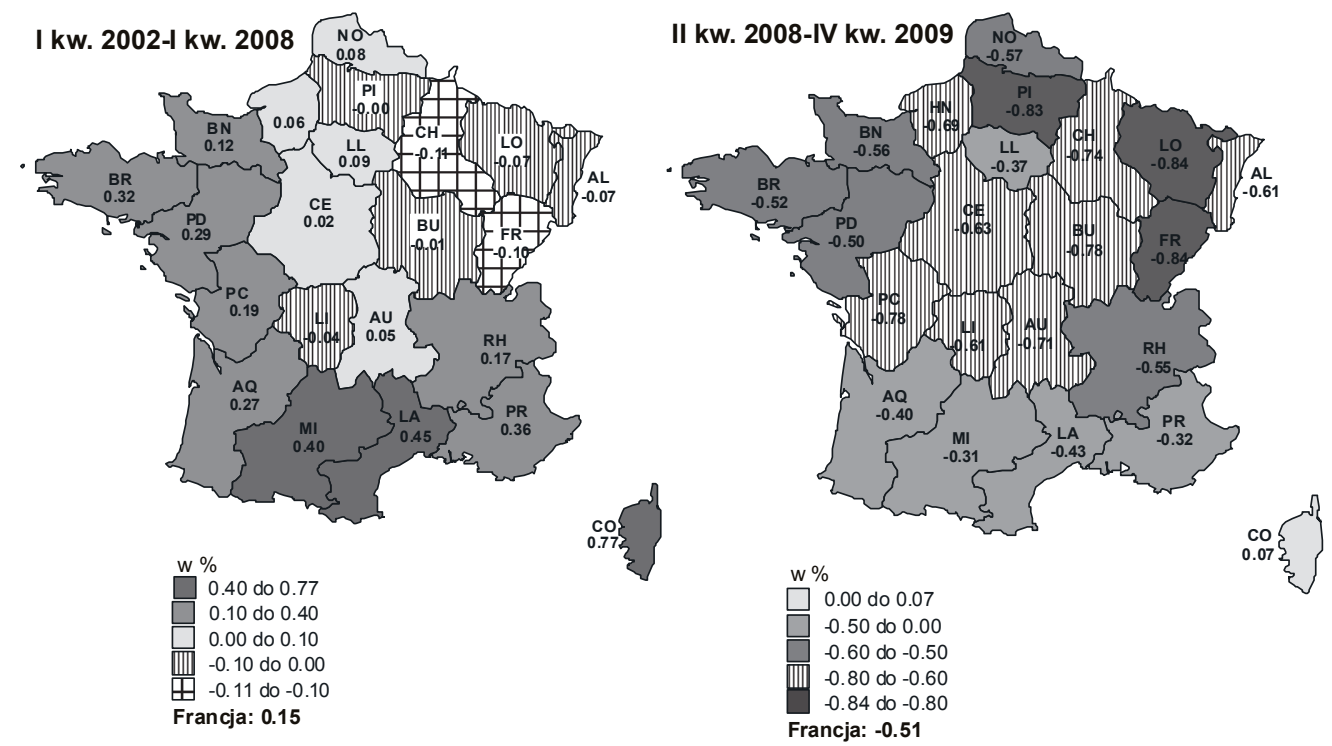

Ryc. 2. Średniokwartalna zmiana wielkości zatrudnienia w regionach Francji w latach 2001-2008 i 2008-2009

Źródło: opracowanie własne na podstawie danych INSEE

Największy spadek zatrudnienia w czasie kryzysu nastąpił w tych regionach Francji, w których w okresie 2002-2008 wystapił już spadek zatrudnienia lub jego wzrost był bardzo niewielki. Zależność ta jest szczególnie widoczna w przypadku wschodnich, przemysłowych regionów. W regionach tych już od początku XXI w. nastąpił wyraźny spadek zatrudnienia związany z procesami transformacji gospodarczej, upadkiem przemysłu ciężkiego i rozwojem przemysłu wysokich technologii oraz sektora usług.

Regionalną zgodność w tendencjach zmiany zatrudnienia w okresie sprzed i w trakcie kryzysu potwierdza wielkość współczynnika korelacji średniokwartalnej zmiany wielkości zatrudnienia w regionach Francji w latach 2001-2008 i 2008-2009 (ryc. 3.A). W zestawieniu tym wyróżniają się swą odmiennością trzy regiony: Île-de-France, Korsyka i PoitouCharentes. W przypadku Korsyki i Île-de-France spadek zatrudnienia był mniejszy niż wynikałoby to z wartości ich wcześniejszych zmian zatrudnienia. Natomiast w regionie PoitouCharentes spadek zatrudnienia był większy i związany był pośrednio z recesją w przemyśle spożywczym, na którą w przypadku Francji nałożyły się niekorzystne skutki zarówno proce- 
sów globalizacyjnych, jak i ustaleń unijnych². Najsilniejsza zależność pomiędzy wielkością tempa spadku zatrudnienia w czasie kryzysu i w okresie go poprzedzającym była zauważalna w ,centrum” recesji gospodarczej, tj. w ostatnim kwartale 2008 i pierwszym kwartale 2009 r. (ryc. 3.B). Nastąpił wówczas we Francji największy spadek zatrudnienia w okresie całego kryzysu. Pod koniec dekoniunktury współczynnik korelacji przyjął wartości ujemne, a następnie zbliżył się do wartości zerowej.

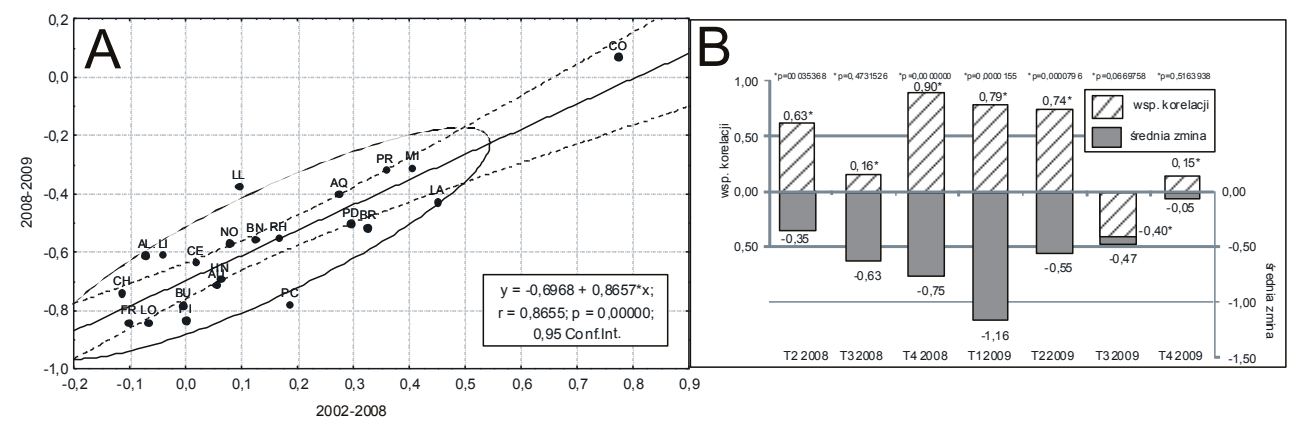

Ryc. 3. Średniokwartalna zmiana wielkości zatrudnienia w regionach Francji w latach 2001-2008 i 2008-2009 (A) oraz ich współczynnik korelacji i średnia wielkość zmiany zatrudnienia (B)

Źródło: opracowanie własne na podstawie danych INSEE

Według typu działalności najszybciej spadek zatrudnienia uwidocznił się w usługach (pierwszy kwartał 2008 r.), a najpóźniej w budownictwie (trzeci kwartał 2008 r.) (ryc. 4). Jedynie w przypadku zatrudnienia w przemyśle nie nastąpiło odwrócenie tendencji na rynku pracy, lecz wzrost tempa spadku zatrudnienia. Według liczby zwolnień największy spadek zatrudnienia nastąpił w sektorze usług (ok. 263,4 tys. osób, co stanowiło 3,2\% liczebności z przed kryzysu) oraz w przemyśle (ok. 247,1 tys.). Spadek zatrudnienia w przemyśle był największy, w odniesieniu do stanu sprzed kryzysu, spośród wszystkich analizowanych działów gospodarki i wynosił 6,9\% w stosunku do początku 2008 r. Tak duży spadek był wynikiem zarówno najszybszego spadku zatrudnienia w porównaniu do innych działów gospodarki, jak i utrzymywania się tej tendencji aż do roku 2010. W przypadku handlu spadek wynosił ok. 66 tys. osób (2,2\%). Natomiast w budownictwie straciło pracę 56,5 tys. pracowników (3,8\%), przy czym spadek ten nie wykazywał wyraźnej tendencji wzrostowej w 2010 r., tak jak miało to miejsce w usługach i handlu. Tak więc w przypadku przemysłu i budownictwa nie można mówić o końcu spadku zatrudnienia.

Według średniokwartalnej zmiany wielkości zatrudnienia we Francji w okresie 2002 2006 i 2008-2009 nastąpiła zmiana tempa zatrudnienia z dodatniego, wynoszącego $0,15 \%$, na ujemne $-0,51 \%$ (ryc. 5). Największe przeobrażanie nastąpiło w budownictwie (z $0,62 \%$ w okresie przed kryzysem do $-0,45 \%$ w czasie kryzysu) i usługach (z $0,38 \%$ do $-0,39 \%$ ). W przemyśle spadek zatrudnienia przyspieszył z średniokwartalnego $-0,5 \%$ do ok. $-1 \%$. Najmniejsza zmiana zatrudnienia nastąpiła w handlu i wynosiła ok. 0,47\%.

${ }^{2}$ Szczególnie recesję w przemyśle spożywczym odczuł przemysł mleczarski, związany z konkurencją wspomaganego przez państwo przemysłu mleczarskiego Niemiec (Bilan économique et social 2009 du Poitou-Charentes, Cahier de Décimal, $n^{\circ}$ 53, Juin 2010). 

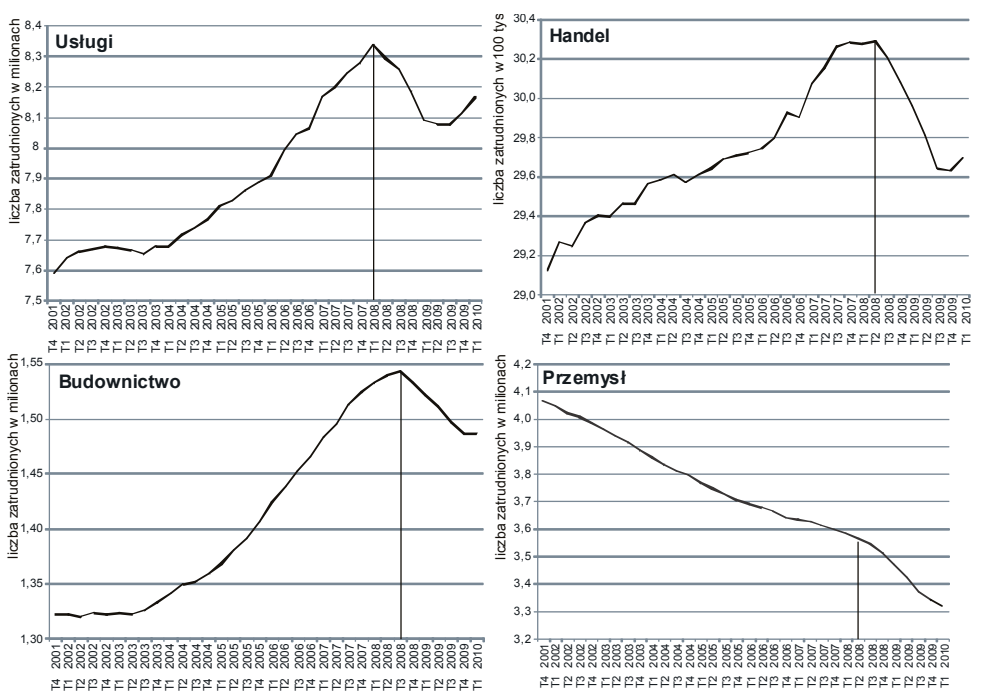

Ryc. 4. Wielkość zatrudnienia we Francji w okresie od IV kw. 2001 do I kw. 2010 wg typu działalności gospodarczej

Źródło: opracowanie własne na podstawie danych INSEE

Analizując współczynnik korelacji regionalnego tempa zmiany wielkości zatrudnienia w okresie kryzysu od zmiany zatrudnienia w okresie poprzednim, można stwierdzić, że był on w przypadku wszystkich typów działalności dodatni. Świadczy to o zgodności kierunku zmian w obu badanych okresach. Najsilniejszy związek między obu badanymi wartościami wystąpił w przypadku zatrudnienia w przemyśle $(0,92)$, zaś mniejszy w przypadku usług $(0,59)$. Potwierdza to w przypadku przemysłu pogłębienie się tendencji istniejących we Francji na rynku pracy przed kryzysem. Natomiast w przypadku budownictwa i handlu spadek zatrudnienia może mieć również podłoże niezwiązane z ekonomią. Działalność ta w dużej mierze zależna jest bowiem od postaw konsumentów wobec kryzysu, które nierzadko są zależne od czynników opiniotwórczych (Pandelica, Pandelica 2009; Harold 2009).
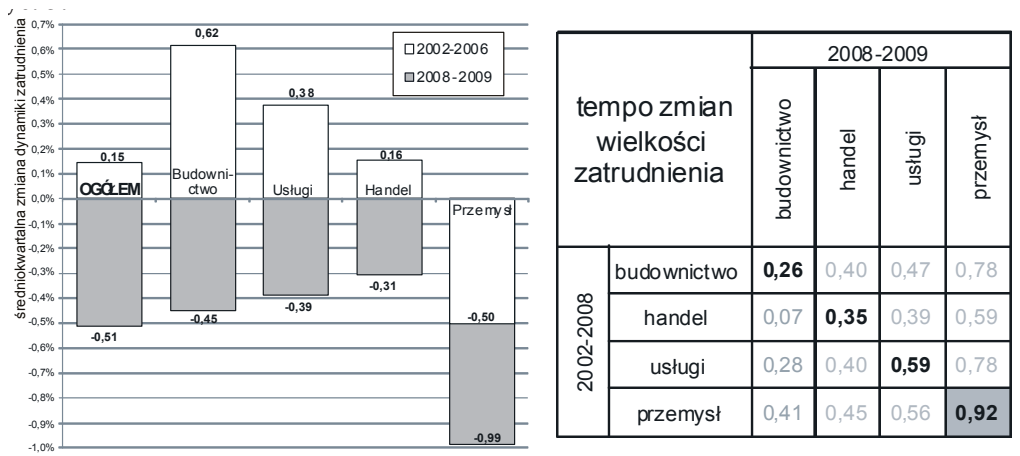

Ryc. 5. Średniokwartalne zmiana wielkości zatrudnienia w regionach Francji

w okresie I kw. 2002-IV kw. 2009 wg typu działalności gospodarczej oraz współczynnik korelacji regionalnego tempa zmiany wielkości zatrudnienia

Źródło: opracowanie własne na podstawie danych INSEE 
Odnosząc się natomiast do analizy regionalnej zależności zmiany tempa zatrudnienia w przemyśle w okresie kryzysu od tempa zmian zatrudnienia w okresie 2002-2008, można zauważyć, że jedynie trzy regiony wykazują wyraźne odchylenie w stosunku do pozostałych regionów (ryc. 6). W przypadku regionu paryskiego spadek zatrudnienia w przemyśle był mniejszy niż wynikałoby to ze zmian zatrudnienia, jakie miały miejsce przed kryzysem. Natomiast w przypadku regionów Pikardii i Górnej Normandii spadki te w czasie kryzysu były większe.

Analizując standaryzowane wartości tempa zmiany zatrudnienia w przemyśle, można stwierdzić, że największy spadek względem wartości zmiany zatrudnienia w przemyśle dla Francji wystąpił $w$ regionach północno-wschodnich i pokrywał się z regionami o największym spadku zatrudnienia w przemyśle w okresie przed kryzysem (ryc. 7). Wyjątkiem są regiony: Île-de-France, Poitou-Charentes, Owernia oraz region Rodańsko-Alpejski, który w okresie kryzysu odnotował spadek zatrudnienia większy od średniej, podczas gdy w okresie przedkryzysowym wartość ta była dodatnia, lecz bliska 0 .
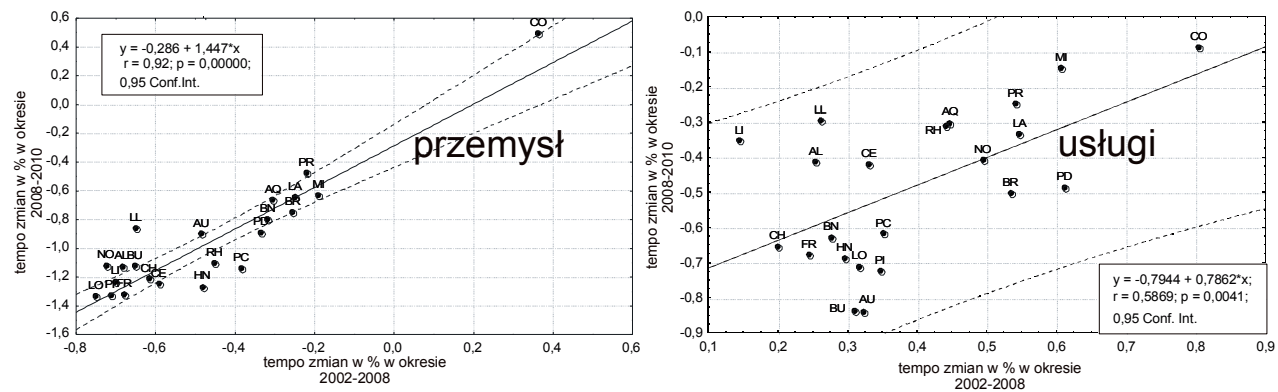

Ryc. 6. Zmiany średniokwartalnego tempa zatrudnienia w przemyśle i usługach w regionach Francji w okresie 2002-2008 i 2008-2010

Źródło: opracowanie własne na podstawie danych INSEE

W przypadku zatrudnienia w usługach związki w obu badanych okresach nie były już tak wyraźnie. Znaczny spadek liczby miejsc pracy względem wartości średnich wystąpił w północno-wschodniej i północno-zachodniej części Francji, największy zaś w Burgundii, Owernii, Lotaryngii i Pikardii. Najniższy spadek zatrudnienia w usługach odnotowały regiony położone na południu kraju (szczególnie Pireneje Środkowe i Prowansja-Alpy-Lazurowe Wybrzeże) i rozwinięte regionach na północy: Île-de-France, Nord-Pas-de-Calais i Alzacja oraz regiony Centrum i Limousin.

W przypadku handlu i budownictwa spadek liczby miejsc pracy wystapił w regionach południowych i północnych, zarówno słabo jak i silniej rozwiniętych. W przypadku zatrudnienia w budownictwie można próbować dostrzec odwrócenie tendencji na rynku pracy. Największy spadek zatrudnienia w czasie kryzysu objął regiony południowo-zachodniej Francji, które w okresie przed 2008 r. charakteryzowały się największym wzrostem miejsc pracy w tej branży (ryc. 8).

Analizując wielkość spadku zatrudnienia w okresie całego kryzysu, widzimy, że największy spadek zatrudnienia odnotował sektor przemysłu (45\% całości analizowanego spadku zatrudnienia) i usługi - 35\%. Największy spadek zatrudnienia w przemyśle (ok. 60\% całości spadku zatrudnienia) wystąpił w rozwiniętych, przemysłowych regionach wschodniej Francji (Franche-Comté, Alzacja i Rodan-Alpy). Najmniejszy spadek zatrudnienia w stosunku 
do ogółu zwolnień (ok. 30\% i mniej) miał miejsce na południu w regionach Prowansja-AlpyLazurowe Wybrzeże i Langwedocja-Roussillon oraz w regionie Paryża. W przypadku usług największy udział tego sektora $\mathrm{w}$ zwolnieniach miejsc pracy był w regionie Île-de-France (48\%), Dolnej Normandii (47\%) i Owernii (45\%). Najmniejszy udział w ogóle zwolnień w usługach wystapił w Midi-Pyrénées (9\%), co było pośrednio wynikiem bardzo dużego udziału zwolnień w budownictwie (25\%). Wysoki udział zwolnień (ok. 20\%) w budownictwie nastąpił również w pozostałych południowo-wschodnich regionach Francji (ryc. 9).

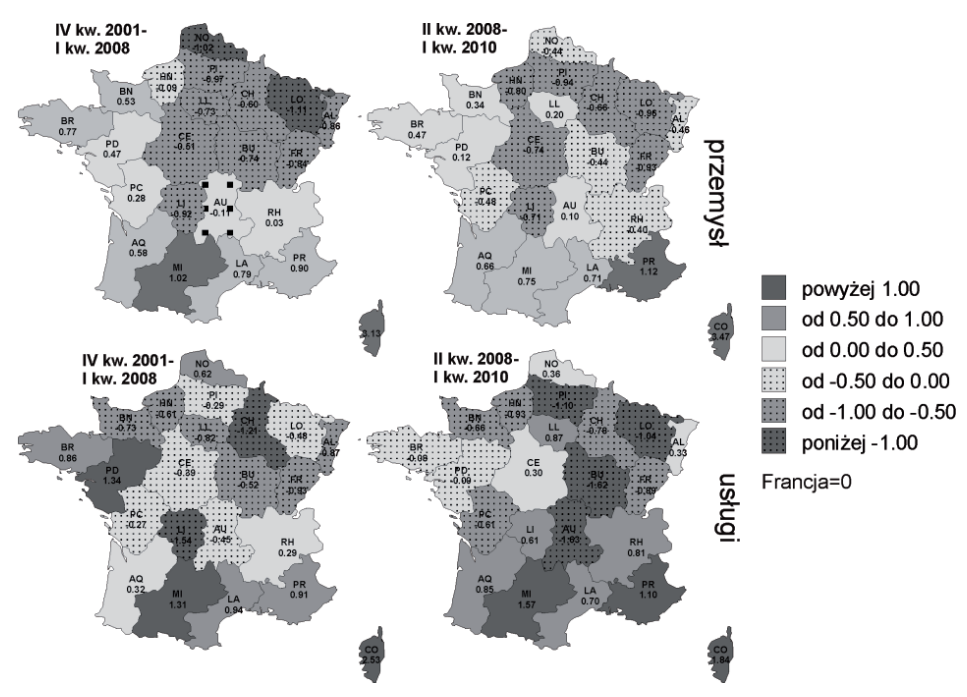

Ryc. 7. Zmiany zatrudnienia w przemyśle i usługach w regionach Francji w okresie IV kw. 2001-I kw. 2008 i II kw. 2008-I kw. 2010 (Francja = 0)

Źródło: opracowanie własne na podstawie danych INSEE

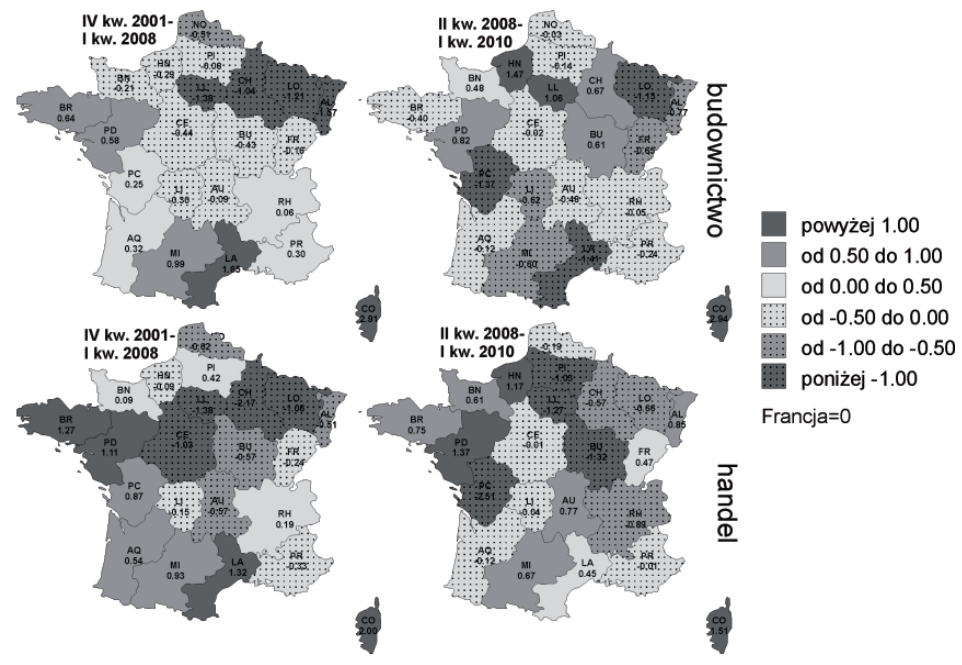

Ryc. 8. Zmiany zatrudnienia w budownictwie i handlu w regionach Francji w okresie IV kw. 2001-I kw. 2008 i II kw. 2008-I kw. 2010 (Francja = 0)

Źródło: opracowanie własne na podstawie danych INSEE 


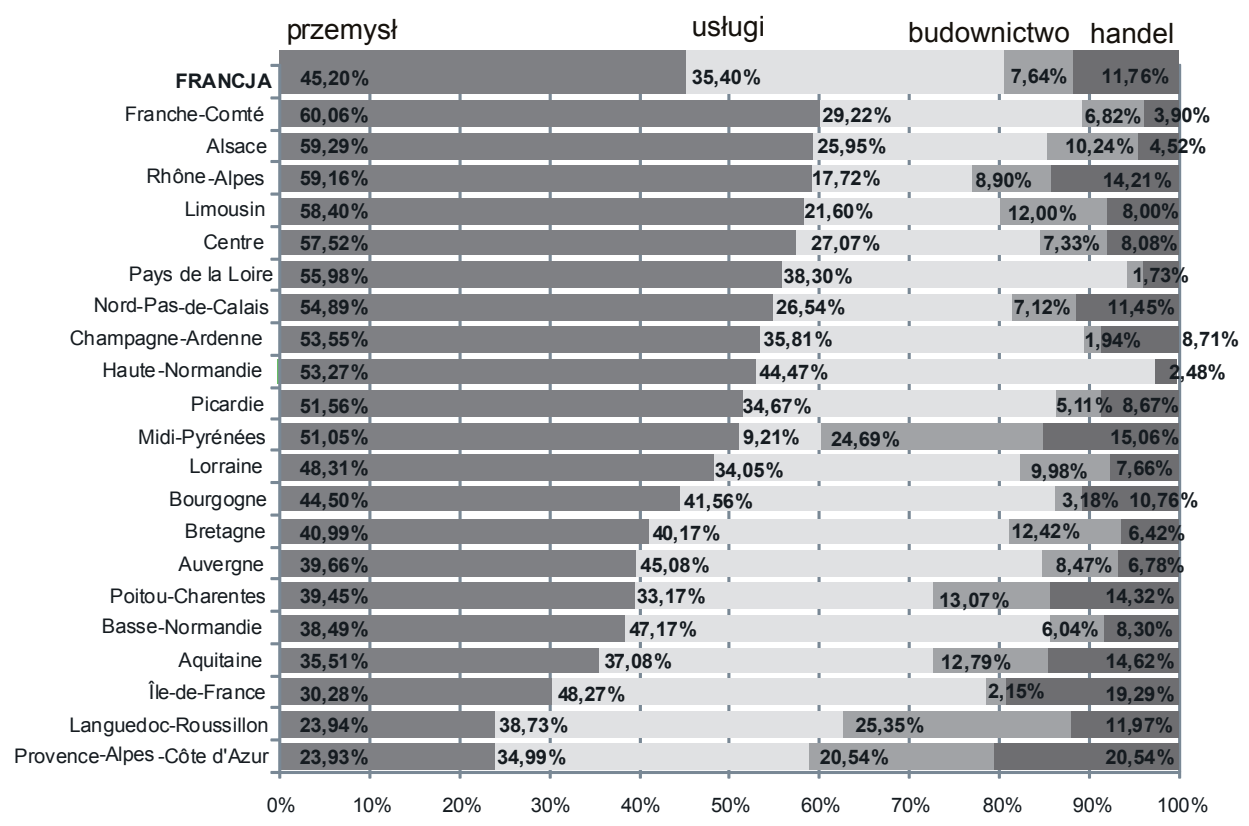

Ryc. 9. Spadek zatrudnienia w regionach Francji wg typu działalności gospodarczej w okresie II kw. 2008-IV kw. 2009

Źródło: opracowanie własne na podstawie danych INSEE
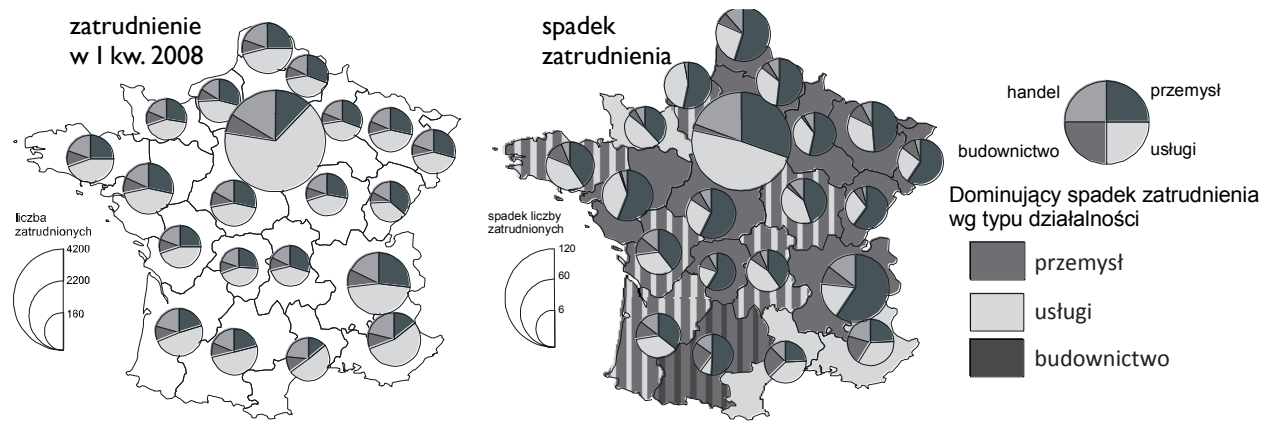

Ryc. 10. Spadek liczby zatrudnionych we Francji w okresie I kw. 2008-IV kw. 2009

wg typu działalności gospodarczej

Źródło: opracowanie własne na podstawie danych INSEE

Nasuwa się zatem pytanie, czy zmiana zatrudnienia w okresie kryzysu nie jest związana $\mathrm{z}$ istniejącą strukturą zatrudnienia $\mathrm{w}$ danych regionach. W tym celu porównano strukturę zatrudnienia na początku 2008 r. i zmianę zatrudnienia w poszczególnych typach działalności gospodarczej w regionach Francji w czasie kryzysu (ryc. 10). Zestawienie to nie wykazało żadnego związku. Spadek zatrudnienia w czasie kryzysu w danym dziale gospodarki nie był uzależniony od istniejącej struktury zatrudnienia w 2008 r. 
Analizując zatem regionalne zróżnicowanie ze względu na przeważający udział spadku zatrudnienia w danym typie działalności gospodarczej, można wydzielić regiony północno-wschodni i wschodni Francji oraz region centralny położone wzdłuż Loary, w których przeważały zwolnienia w przemyśle. W regionach południowych oraz w mniejszym stopniu na północnym zachodzie dominował spadek zatrudnienia głównie w usługach lub spadek ten był porównywalny ze spadkiem miejsc pracy w przemyśle. Było to zauważalne zwłaszcza w przypadku regionów rozwijających się. Jedynie w przypadku regionu Midi-Pyrénées zwolnienia w budownictwie miały podobną wielkość jak zwolnienia w przemyśle.
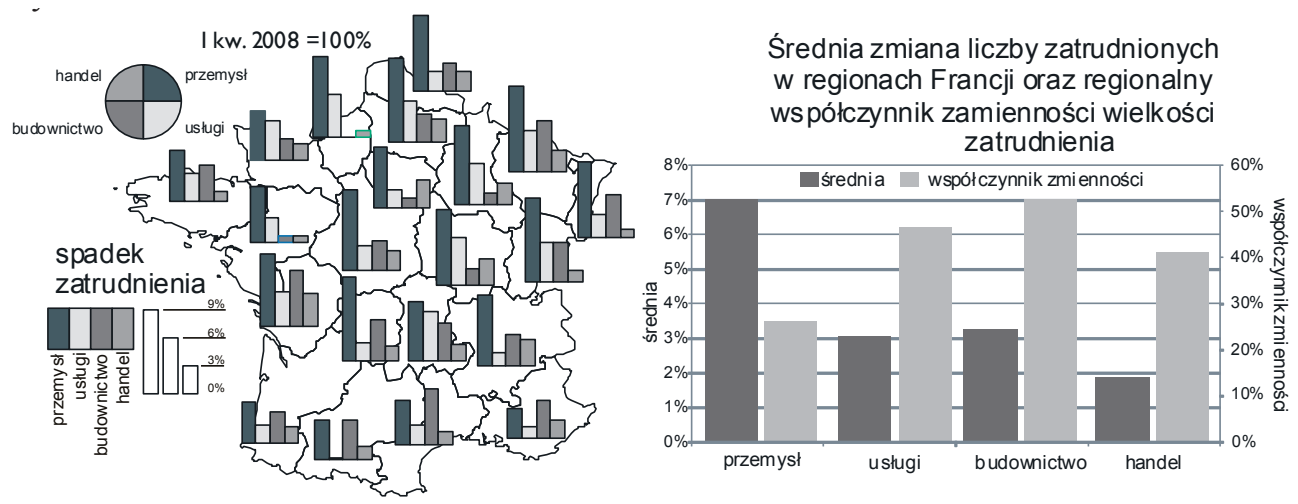

Ryc. 11. Spadek liczby zatrudnionych we Francji w okresie I kw. 2008-IV kw. 2009 wg typu działalności

Źródło: opracowanie własne na podstawie danych INSEE

Rozpatrując regionalny spadek zatrudnienia w okresie kryzysu finansowego w stosunku do pierwszego kwartału 2008 r., można zauważyć, że prawie we wszystkich regionach Francji największy spadek zatrudnienia nastąpił w sektorze przemysłu (ryc. 11). Jedynie w regionach południowych największy spadek zatrudnienia w stosunku do 2008 r. odnotowano w budownictwie. Na drugim miejscu według spadku zatrudnienia w odniesieniu do wielkości sprzed kryzysu znalazły się usługi (regiony centralne) oraz budownictwo (regiony południowe). Zwolnienia w handlu miały miejsce głównie w regionie paryskim oraz sąsiednich regionach: Szampanii i Burgundii. Można zatem przyjąć, że powszechnym procesem we Francji w czasie kryzysu, niezależnym od początkowego stanu gospodarki regionów, był spadek zatrudnienia w przemyśle. Potwierdza to współczynnik regionalnej zmienności zatrudnienia, który w analizowanych sektorach w przypadku przemysłu jest najmniejszy i wynosi $25 \%$, podczas gdy w przypadku pozostałych sektorów waha się pomiędzy $40 \%$ i $50 \% \mathrm{w}$ budownictwie.

Analiza szczegółowego czasowego zestawienie spadku zatrudnienia w regionach potwierdza w przypadku Francji przedział trwania kryzysu od II kw. 2008 do IV kw. 2009 (tab. 1). Jedynie w przypadku budownictwa kryzys uwidocznił się później, w IV kw. 2008 roku. Spadek zatrudnienia rozpoczął się regionach północno-wschodnich i w regionach Masywu Centralnego, obejmując następnie całą północną część kraju. Jako ostatnie procesowi recesji na rynku pracy uległy regiony południowe i zachodnie, w których też proces ten najszybciej się zakończył. Można zatem przyjąć, że najwcześniej spadek zatrudnienia nastąpił w rozwiniętych gospodarczo i przemysłowych regionach wschodniej i północnej Francji. 
Tam też zwolnienia wśród pracowników osiągnęły największe wartości (ryc. 12). Odnosi się to głównie do regionów północnych i wschodnich, tj. Alzacji, Franche-Comté, Nord-Pasde-Calais, Pikardii, Dolnej i Górnej Normandii. Regionami o dużym spadku liczby miejsc pracy były regiony położone na zachód od Masywu Centralnego: Limousin i Poitou-Charentes. Obszarami o najmniejszym spadku zatrudnienia były z kolei regiony południowe i zachodnie Francji. Na południu były to regiony od Akwitanii na zachodzie po region Prowansja-AlpyLazurowe Wybrzeże na wschodzie. Ponadto mało zwolnień wśród pracowników odnotowano w Bretanii i Krainie Loary.

W analizie według typu działalności gospodarczej można zauważyć wyraźne nasilenie spadku zatrudnienia w usługach (od II kw. 2008 do II kw. 2009) oraz przemyśle (trwające od III-IV kw. 2008). Wyraźnie zaznaczył się również spadek zatrudnienia w budownictwie (IV kw. 2008 - I kw. 2009). Porównując zatem tempo spadku zatrudnienia w poszczególnych regionach Francji, na podstawie wcześniej przeprowadzonych analiz dokonano typologii poszczególnych jednostek administracyjnych. Analizę ograniczono do dziewiętnastu regionów, eliminując regiony, w których procesy związane ze zmianą zatrudnienia przebiegały inaczej niż w pozostałych regionach. Wykluczono zatem wyspiarski region Korsyki, gdzie procesy ekonomiczne przebiegają odrębnie od reszty Francji. Wynika to głównie z uwarunkowań administracyjno-prawnych związanych $\mathrm{z}$ autonomią regionu. Pominięto również region Île-de-France ze względu na historyczną dominację ekonomiczną Paryża i region Alzacji, w którym nastąpił wyjątkowo duży spadek zatrudnienia powiązany z ogólnym procesem transformacji przemysłu oraz powiązaniami eksportowymi z sąsiednimi krajami.

W wyniku przeprowadzenia analizy skupień z wykorzystaniem odległości euklidesowej w oparciu o zmiany zatrudnienia w przemyśle, usługach, handlu i budownictwie od I kw. 2008 do I kw. 2010 wyróżniono pięć typów regionów (ryc. 13). Regionami o podobnym (najwyższym) spadku zatrudnienia $\mathrm{w}$ analizowanych typach działalności gospodarczej są: Franche-Comté, Owernia, Poitou-Charentes oraz Dolna i Górna Normandia. Innymi regionami o podobnej wielkości zmiany zatrudnienia w okresie kryzysu były regiony: Nord-Pasde-Calais, Pikardia, Lotaryngia i Limousin.

Następnie według podobieństwa spadku zatrudnienia zostały wyróżnione regiony: Akwitania, Bretania i Prowansja-Alpy-Lazurowe Wybrzeże oraz Midi-Pyrénées, Kraina Loary, Burgundia i region Rodańsko-Alpejski.

Zróżnicowanie regionalne Francji co do zmiany wielkości zatrudnienia w trakcie kryzysu finansowego w latach 2008-2009 można powiązać z poziomem rozwoju gospodarczego w oparciu o wielkość PKB w przeliczeniu na wielkość zatrudnienia. Zarówno w okresie kryzysu, jak i okresie go poprzedzającym (2006-2007) największy spadek zatrudnienia wystapił w regionach o najniższej wartości PKB w okresie sprzed kryzysu (ryc. 14). Wyjątek stanowią regiony pominięte w analizie skupień, tj. Korsyka i region stołeczny Francji oraz region Górnej Normandii. 


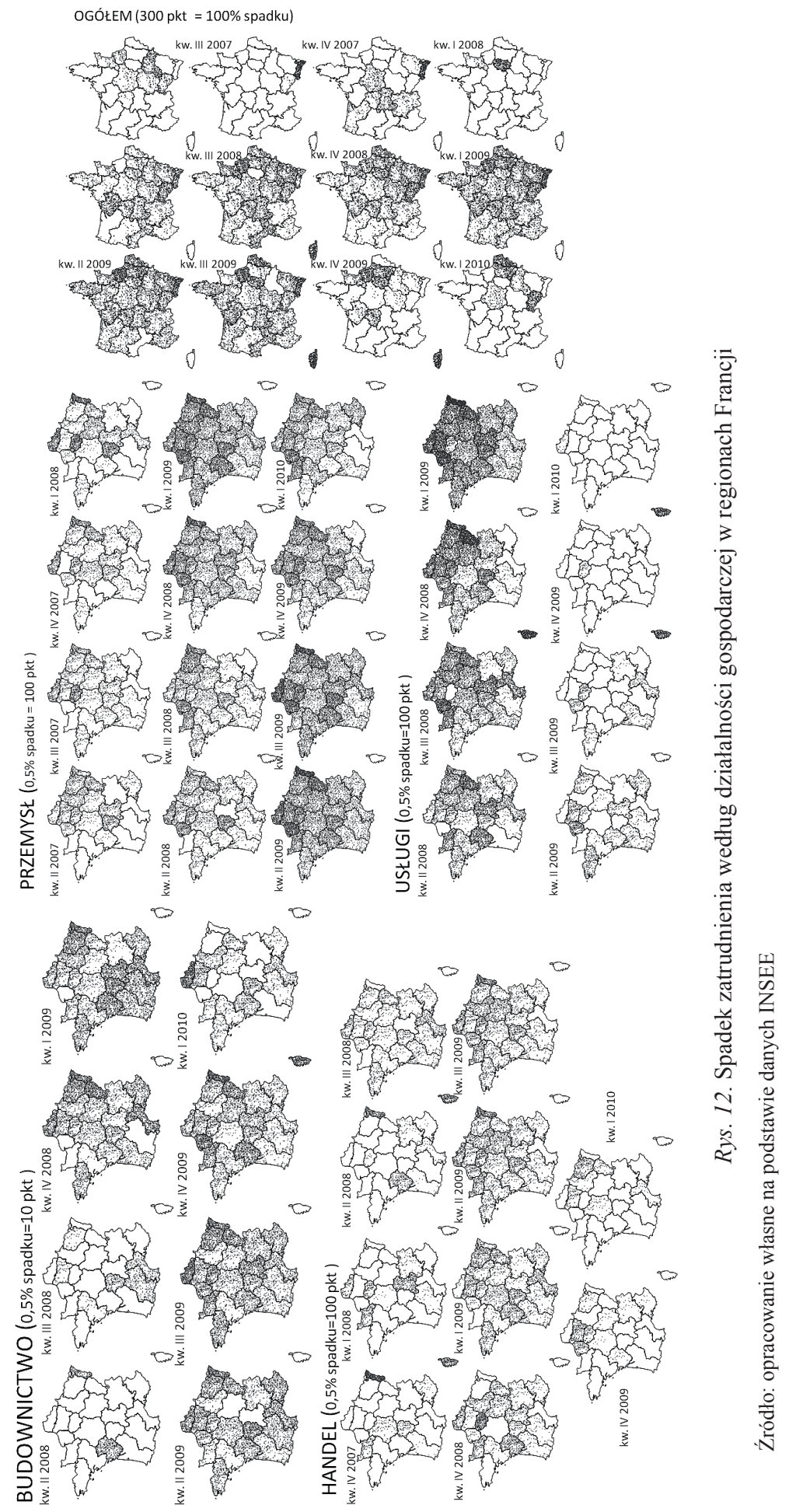


Tab. 1. Kwartalna zmiana zatrudnienia w regionach Francji latach 2007-2010

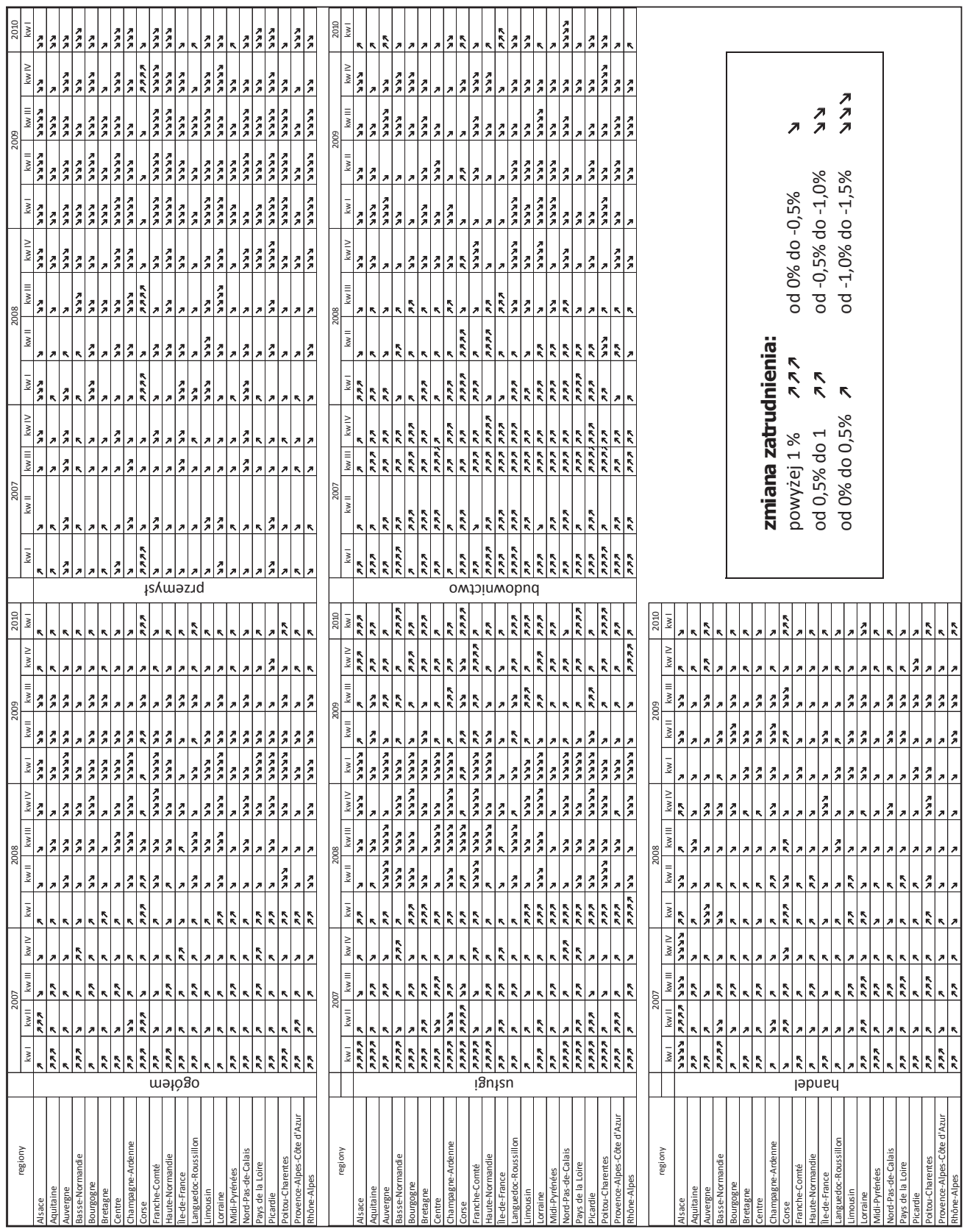

Źródło: opracowanie własne na podstawie danych INSEE 


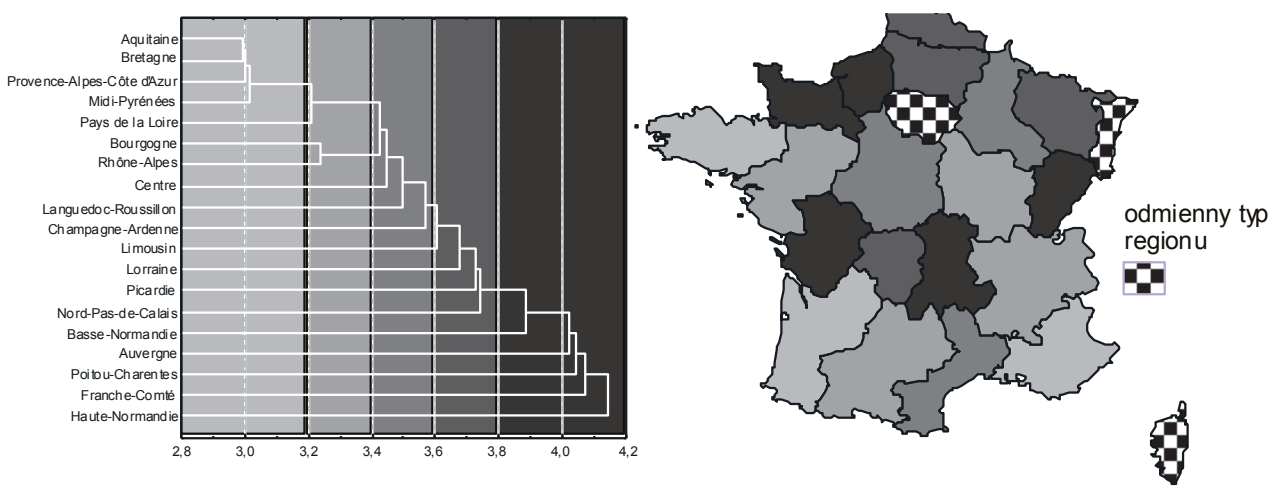

Ryc. 13. Typy regionów Francji według struktury zmian zatrudnienia w analizowanych typach działalności gospodarczej

Źródło: opracowanie własne na podstawie danych INSEE

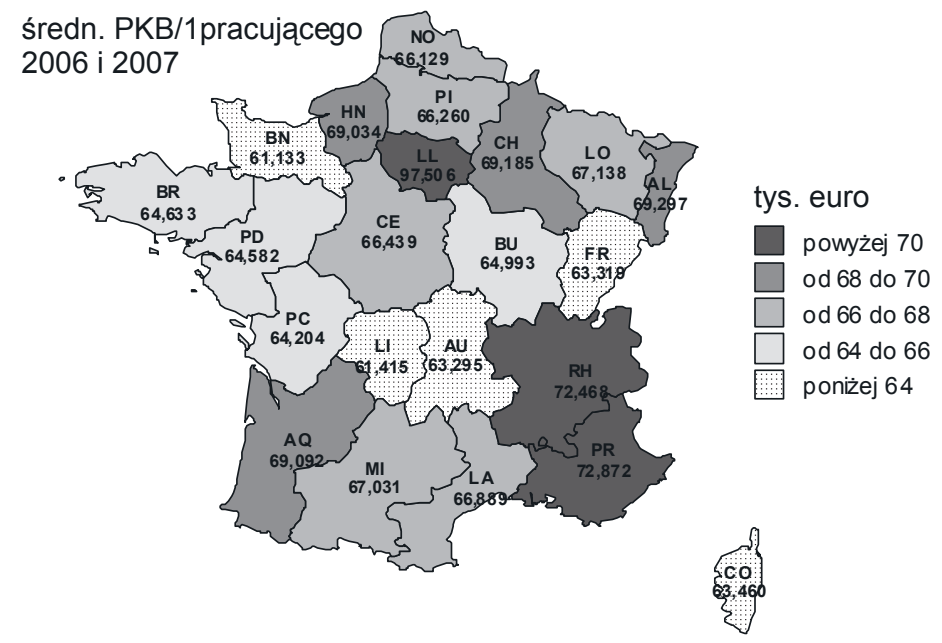

Ryc. 14. Średnia wielkość PKB w regionach Francji dla okresu 2006-2007

Źródło: opracowanie własne na podstawie danych INSEE

\section{ZMIANY POZIOMU ROZWOJU EKONOMICZNEGO FRANCJI}

Następnym zagadnieniem jest związek regionalnego spadku zatrudnienia w czasie kryzysu finansowego z poziomem rozwoju gospodarczego regionów Francji. Ogólnie można stwierdzić, że wielkość spadku PKB w okresie kryzysu była ściśle związana z poziomem PKB w okresie poprzedzającym kryzys (ryc. 15). 


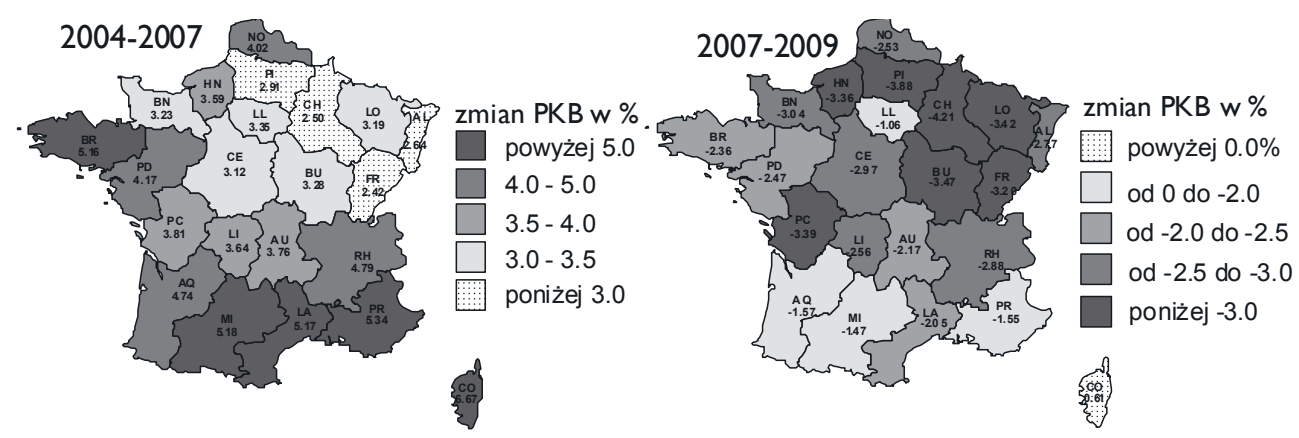

Ryc. 15. Średnia zmiana wartości PKB w regionach Francji w latach 2004-2007 i 2008-2009

Źródło: opracowanie własne na podstawie danych INSEE

Powyższe stwierdzenie o zależności średniego tempa zmian wielkości PKB w okresie przed i w czasie kryzysu finansowego potwierdza zestawienie graficzne obu analizowanych wartości oraz wielkość współczynnika korelacji $(0,77)$ (ryc. 16). Jedynie w przypadku Île-de-France i Korsyki zależność ta nie została zachowana. Natomiast w zestawieniu zmiany wielkości PKB oraz tempa spadku zatrudnienia tylko w przypadku wartości ogólnej PKB można mówić o zależności statystycznej (tab. 1). Wydaje się zatem prawdziwe stwierdzenie, że spadek zatrudnienia we Francji objął głównie regiony o najniższym tempie rozwoju ekonomicznego, lecz posiadające wysoki poziom rozwoju gospodarki oraz regiony z wysokim tempem rozwoju ekonomicznego, lecz o bardzo niskim poziomie rozwoju gospodarczego.

Z zestawienia zmiany wielkości PKB w okresie 2004-2007 i zmiany wielkości zatrudnienia w czasie recesji można zauważyć dodatnią zależność $(r=0,83)$, co świadczy, że największy spadek zatrudnienia w okresie kryzysu nastąpił w tych regionach Francji, które przed kryzysem miały najniższe tempo wzrostu PKB. Zależność ta jest szczególnie widoczna w przypadku spadku zatrudnienia w usługach $(\mathrm{r}=0,86)$ i przemyśle $(\mathrm{r}=0,84)$.

Ryc. 16. Średnia zmiana wartości PKB w regionach Francji w latach 2004-2007 i 2008-2009

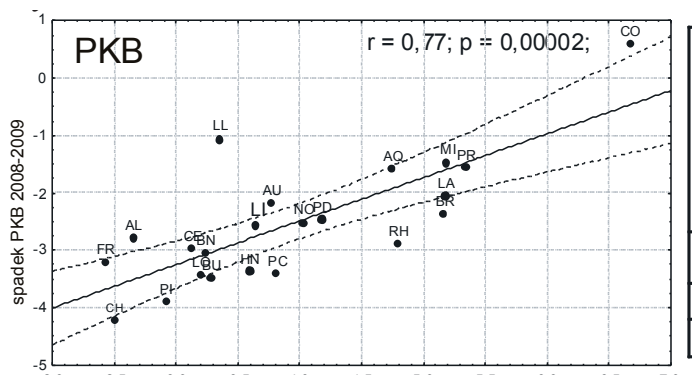

Tab. 2. Wielkość współczynnika korelacji pomiędzy wielkością PKB i zmianą wielkości zatrudnienia

\begin{tabular}{|c|c|c|c|c|c|}
\hline \multirow[b]{2}{*}{$\begin{array}{c}\begin{array}{c}\text { zmiana } \\
\text { PKB }\end{array} \\
2004-2007 \\
\end{array}$} & \multicolumn{5}{|c|}{ zmiana zatrudnienia 2008} \\
\hline & $\begin{array}{l}\frac{E}{0} \\
\frac{0}{0} \\
\frac{0}{0}\end{array}$ & 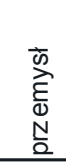 & 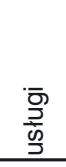 & 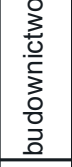 & 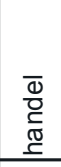 \\
\hline PKB & 0,83 & 0,84 & 0,86 & 0,23 & 0,32 \\
\hline PKB/os. & 0,18 & 0,09 & 0,14 & $-0,28$ & 0,00 \\
\hline $\mathrm{PKB} /$ pracujcego & 0,51 & 0,53 & 0,53 & 0,02 & 0,16 \\
\hline
\end{tabular}

Źródło: opracowanie własne na podstawie danych INSEE 

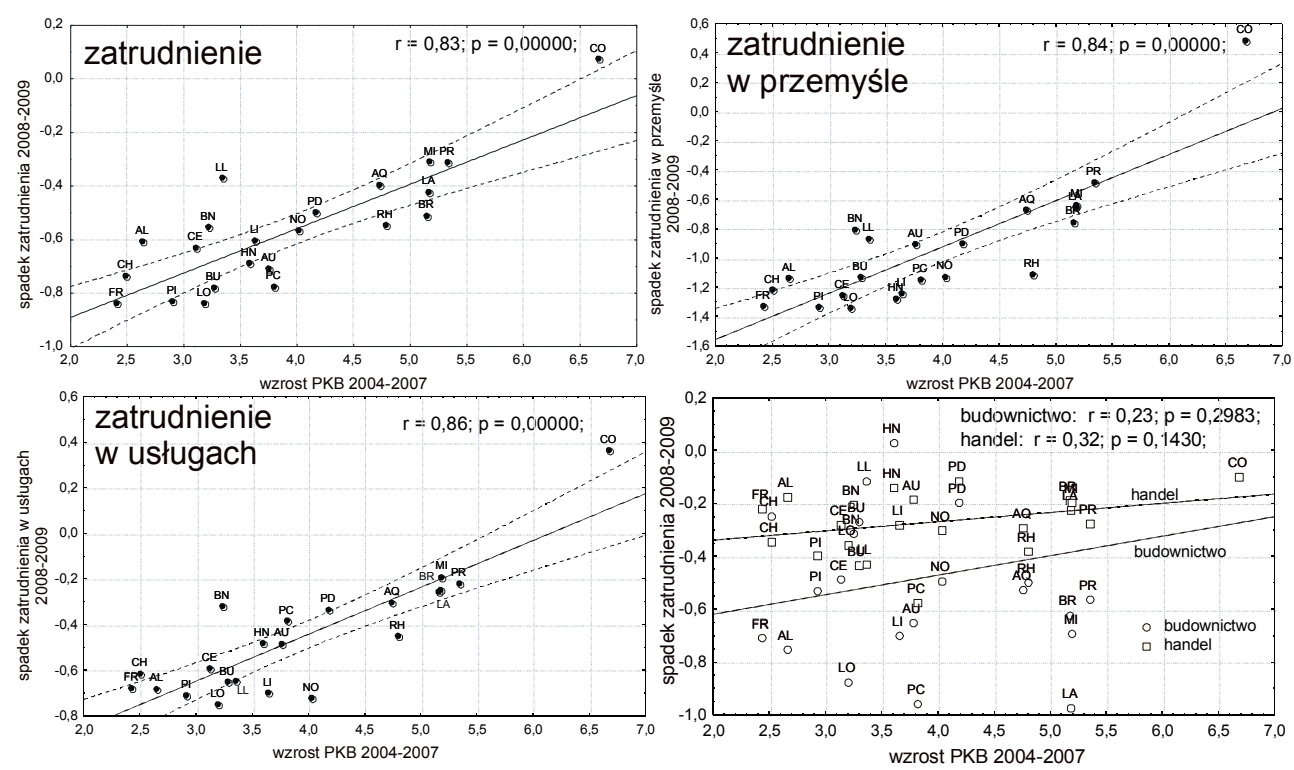

Ryc. 17. Zmiany wielkości PKB w 2004-2007 i zatrudnienia w 2008-2010 w regionach Francji (\%)

Źródło: opracowanie własne na podstawie danych INSEE

W przypadku zwolnień w budownictwie i handlu powyższe związki nie występowały. Spadek zatrudnienia dotknął zarówno regiony o słabym tempie jak i o szybkim rozwoju ekonomicznym. Może to mieć związek z charakterem obu tych typów działalności gospodarczej uzależnionych nie tylko od globalnych uwarunkowań ekonomicznych, lecz w większym stopniu od lokalnych warunków i odczuć społeczeństwa.

W okresie kryzysu można zauważyć również związek między spadkiem zatrudnienia i spadkiem wartości PKB w regionach Francji. Średnio 10-procentowemu regionalnemu spadkowi PKB towarzyszył 1,7-procentowy spadek zatrudnienia (ryc. 18). W przypadku przemysłu spadek zatrudnienia $\mathrm{w}$ stosunku do PKB był wyższy i wynosił 3,5\%. Jednakże trzeba pamiętać, że w przypadku przemysłu kryzys spowodował jedynie dwukrotne przyśpieszenie spadku zatrudnienia. Tak więc uwzględniając ten fakt, trzeba uznać, że również w przypadku przemysłu spadek zatrudnienia miał wartości zbliżone do ogólnego spadku zatrudnienia we Francji.

$\mathrm{Na}$ koniec dokonano próby weryfikacji tezy o spadku regionalnych różnic w poziomie rozwoju ekonomicznego w okresie kryzysu we Francji. W porównaniu stopnia poziomu ekonomicznego posłużono się zarazem wartościami bezwzględnymi (wielkość PKB), jak i wielkościami względnymi, tj. wartość PKB w przeliczeniu na liczbę mieszkańców i zatrudnionych w regionach Francji.

W celu zweryfikowania zróżnicowania w poziomie rozwoju ekonomicznego wykorzystano wskaźnik odchylenia standardowego. Na podstawie analizy otrzymanych wyników trudno potwierdzić tezę o zmniejszeniu różnic międzyregionalnych w poziomie rozwoju gospodarczego Francji. We wszystkich analizowanych przypadkach zarówno w odniesieniu do poziomu PKB ogółem, jak i w przeliczeniu na liczbę ludności lub zatrudnionych, międzyregionalne zróżnicowanie w latach 1990-2010 wciąż wzrastało. 

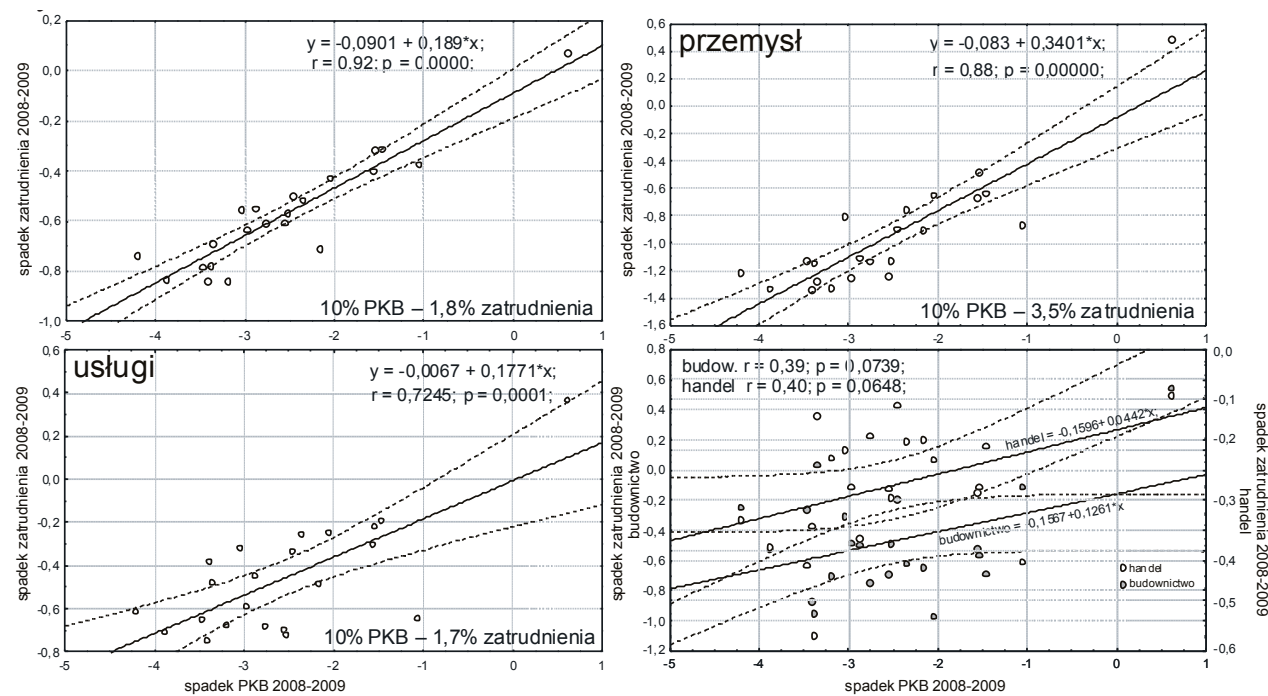

Ryc. 18. Zmiana zatrudnienia i wielkości PKB w 2008-2009 w regionach Francji (\%)

Źródło: opracowanie własne na podstawie danych INSEE

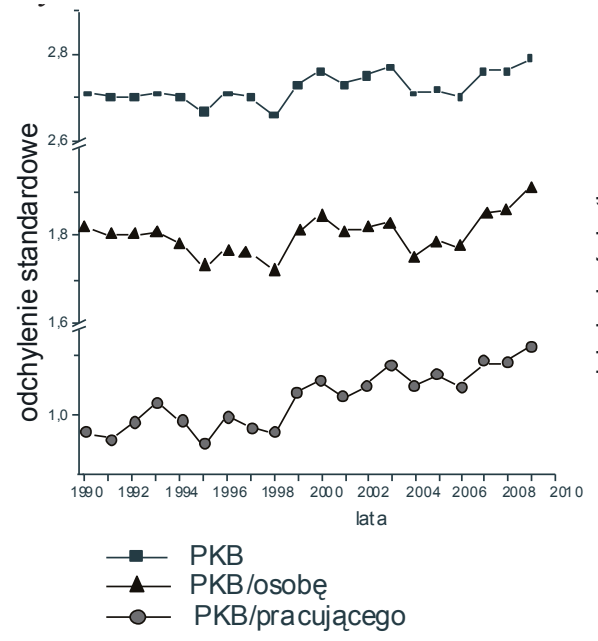

współczynnik zmienności bez regionów: île-de-France i Korsyka
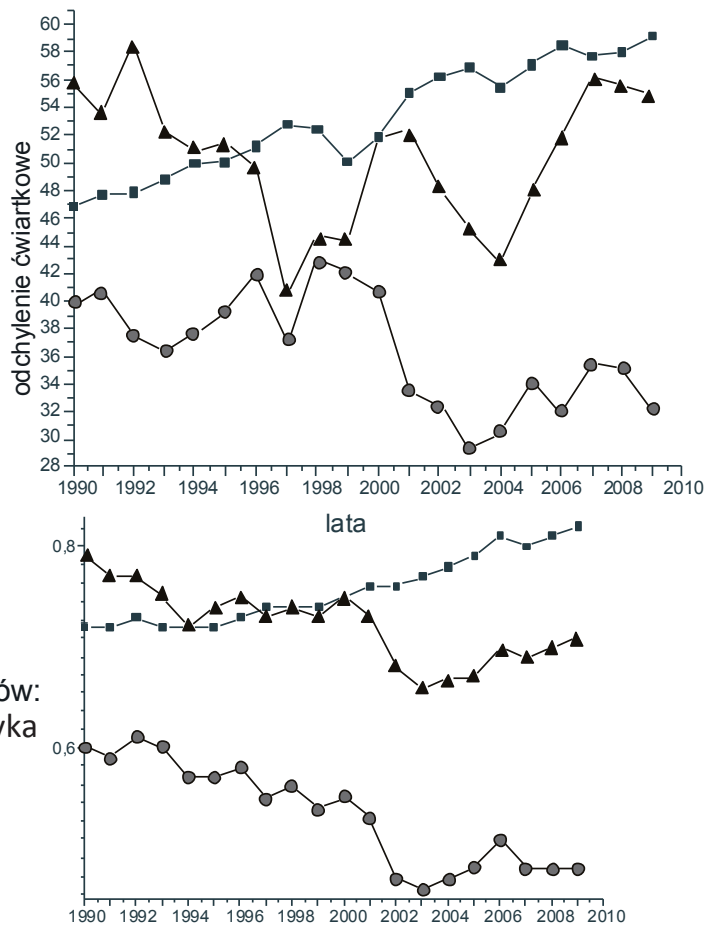

lata

Ryc. 19. Zróżnicowanie poziomu rozwoju gospodarczego we Francji w latach 1990-2009 Źródło: opracowanie własne na podstawie danych INSEE 
W dalszych badaniach poddano analizie regiony o zbliżonych do średniej krajowej wartościach poziomu rozwoju. W tym celu obliczono odchylenie ćwiartkowe na podstawie wybranych wskaźników związanych z poziomem PKB w regionach. W zestawieniu wartości centralnych można zauważyć, że zróżnicowanie w poziomie rozwoju gospodarczego od 2008 r. maleje, zarówno w przeliczeniu na liczbę mieszkańców, jak i liczbę zatrudnionych. Świadczy to o ciąłej dominacji ekonomicznej regionów rozwiniętych oraz o istnieniu regionów o bardzo niskim poziomie rozwoju. Dlatego w celu porównania zróżnicowania ekonomicznego wśród typowych regionów pominięto w analizie skrajne wartości, tj. Îlede-France i Korsykę. W układzie tym można mówić o procesie wyrównywania poziomów nie tylko w odniesieniu do okresu kryzysu, lecz również lat 90. XX w. Dlatego należy przyjąć, że zmniejszenie regionalnego poziomu rozwoju regionalnego w okresie kryzysu odnosiło się jednie do połowy regionów Francji z wartościami rozwoju zbliżonymi do wartości średniej.

\section{WNIOSKI}

Globalny kryzys finansowy, który rozpoczął się w 2008 r., doprowadził w latach 20082009 do globalnej recesji gospodarki. Spowodowało to dramatyczne konsekwencje na rynku pracy w wielu krajach świata. Wprawdzie w dokonanej analizie uwzględniono jedynie wielkość zatrudnienia na podstawie umowy o pracę, pomijając np. samozatrudnienie, jednakże wydaje się prawidłowe domniemanie, że recesja na rynku pracy spowodowana globalną sytuacją gospodarczą w podobnym stopniu dotyczyła firm jednoosobowych, jak i pracowników najemnych. Inna wątpliwość związana jest z liczbą zwolnionych osób, ponieważ $\mathrm{w}$ wielu przedsiębiorstwach podjęto środki przeciwdziałające zwolnieniom, tj. wprowadzono bezpłatne urlopy lub skrócenie czasu pracy (a co za tym idzie zmniejszenie płacy). Jednakże również w tym przypadku przyjęto, że działania te nie wpłynęły w sposób znaczący na regionalne zróżnicowanie zmiany liczby zatrudnionych w okresie kryzysu finansowego, gdyż miało ono takie samo natężenie w poszczególnych regionach. Zdając sobie sprawę z powyższych założeń, podsumowano dokonaną w artykule próbę przełożenie zaistniałych w czasie kryzysu prawidłowości makroekonomicznych na układ regionalny Francji.

Pierwszym z podjętych w tekście zagadnień było zweryfikowanie hipotezy o istnieniu regionalnego zróżnicowania wielkości spadku zatrudnienia w czasie kryzysu. Powyższe stwierdzenie zostało pozytywnie zweryfikowane w przypadku spadku zatrudnienia w przemyśle i usługach. Regiony o przewadze spadku zatrudnienia w przemyśle występują w północnej i wschodniej części kraju, podczas gdy spadek zatrudnienia w usługach odnotowano głównie na południu i zachodzie. W analizie pominięto kwestię zróżnicowania w danym typie działalności gospodarczej. Jednakże z wcześniejszych badań (Dorocki 2008a; Dorocki, Jenner 2008, 2009) wynika, że spadek zatrudnienia w przemyśle bardzo silnie powiązany był z restrukturyzacją przemysłu i rozwojem przemysłu wysokich technologii. Regiony północne i wschodnie historycznie związane były z przemysłem ciężkim (Dorocki 2008b). Natomiast w regionach południowych i zachodnich, a w szczególności w Basenie Akwitańskim i w Bretanii, po okresie stagnacji gospodarczej w wyniku polityki regionalnej i interwencji państwa zaczął rozwijać się nowoczesny przemysł. Południe Francji w myśl planów rozwoju tzw. Golden lub Yellow Banana ma stać się częścią obszaru innowacji i rozwoju wysokiej 
technologii. O powodzeniu tych działań może świadczyć zarówno wysokie tempo wzrostu gospodarczego, jak i napływ inwestycji, w tym inwestycji zagranicznych.

Dlatego spadek zatrudnienia w przemyśle w czasie kryzysu jedynie uległ przyspieszeniu, natomiast nie zaobserwowano zmiany przestrzennej. Największy spadek liczby miejsc pracy w przemyśle odnotowano w regionach, które przed 2008 r. również posiadały najwyższe ujemne tempo zmian zatrudnienia w przemyśle. W przypadku zatrudnienia w usługach prawidłowości te nie były już tak wyraźne. Jednakże można przyjąć, że większe ubytki miejsc pracy w usługach nastapiły na północy i wschodzie Francji.

Rynek pracy w budownictwie i handlu nie wykazywał już tak wyraźnych prawidłowości, choć i w tym przypadku odmienne tendencje panują w regionach śródziemnomorskich, w Bretanii i Normandii oraz na wschodzie Francji. Spośród wszystkich regionów wyróżnia się Korsyka, która w przeciwieństwie do pozostałych regionów, pomimo wyraźnego obniżenia, utrzymała wzrost zatrudnienia. Również region paryski, ze względu na swój dominujący charakter i pozycję w gospodarce Francji, w sposób łagodniejszy od sąsiednich regionów odczuł regres na rynku pracy. Jednym z zachodnich regionów, w których wystąpił bardzo duży spadek zatrudnienia, był atlantycki region Poitou-Charentes. Związane było to z bardzo dużym udziałem w tym regionie przemysłu spożywczego (zwłaszcza mleczarskiego), który ze względu na swój eksportowy charakter odczuł w sposób szczególny kryzys światowy. Należy tu zwrócić uwagę, że wszelkie działania podjęte na rzecz wzrostu zatrudnienia we Francji opierały się głównie na rozwoju innowacyjnych inwestycji.

Następnym problemem było pytanie o związek pomiędzy spadkiem zatrudnienia a poziomem rozwoju gospodarczego regionów. Również i w tym przypadku związek ten jest widoczny wyłącznie w odniesieniu do zatrudnienia w przemyśle i usługach. Mniejszy spadek zatrudnienia nastapił $\mathrm{w}$ regionach rozwiniętych gospodarczo z wysokim tempem wzrostu wielkości PKB. Zależność ta szczególnie widoczna była w przypadku zmiany zatrudnienia w przemyśle i usługach, które stanowiły największy odsetek wszystkich zwolnień. Należy zatem odrzucić hipotezę, że we Francji kryzys w większym stopniu dotknął rynek pracy $\mathrm{w}$ regionach bogatych niż biednych. Również w tym przypadku mniejsze straty w liczbie zatrudnionych niż wynikało to z wartości średnich dla Francji odnotowały regiony: Île-deFrance i Korsyka, natomiast większy od wartości średnich Rodan-Alpy.

Na koniec dokonano próby odpowiedzi na pytanie, czy w okresie kryzysu finansowego zmalała przepaść ekonomiczna pomiędzy regionami Francji. Jako metodę statystyczną wybrano wskaźnik zróżnicowania wielkości PKB oparty o odchylenie standardowe i odchylenie ćwiartkowe. Według otrzymanych wyników jedynie w przypadku wyników odchylenia ćwiartkowego wielkości PKB w przeliczeniu na wielkość zaludnienia regionu lub liczbę pracujących można zauważyć spadek międzyregionalnego zróżnicowania poziomu rozwoju gospodarczego, jednakże jest on widoczny już od 2007 r. Dlatego zrównanie poziomu ekonomicznego występuję jedynie pomiędzy regionami o średnim stopniu rozwoju gospodarczego i nie można wiązać tego faktu jedynie z wpływem światowego kryzysu finansowego.

Tak więc większość założeń związanych z wpływem kryzysu na rynek pracy w krajach europejskich w przypadku regionów Francji zostało odrzuconych. 


\section{Literatura}

Choudhry M.T., Marelli E., Signorelli M., 2010, The Impact of Financial Crises on Labor Markets-A Gender Perspective, The 11th bi-annual EACES conference, University of Tartu, August 26-28.

Dorocki S., 2008 b, Ksztattowanie się regionów przemysłowych Francji, [w:] Procesy transformacji układów przestrzennych przemystu na tle zmieniajacego się otoczenia, red. Z. Zioło, T. Rachwał, Prace Komisji Geografii Przemysłu PTG, nr 10, Komisja Geografii Przemysłu PTG i Zakład Przedsiębiorczości i Gospodarki Przestrzennej Instytutu Geografii Akademii Pedagogicznej w Krakowie, Warszawa-Kraków 2008, s. 45-54.

Dorocki S., 2008 a, Gospodarka oparta na wiedzy w zatożeniach Strategii Lizbońskiej - na przykładzie Francji, [w:] Rola przedsiębiorczości w gospodarce opartej na wiedzy, red. Z. Zioło, T. Rachwał, Zakład Przedsiębiorczości i Gospodarki Przestrzennej Instytutu Geografii Akademii Pedagogicznej w Krakowie, Wydawnictwo Nowa Era, Kraków-Warszawa, s. 176-183.

Dorocki S., Jenner B., 2008, Regionalne zróżnicowanie rozwoju ekonomicznego Francji, [w:] Przekształcenia regionalnych struktur funkcjonalno-przestrzennych. Europa bez granic - nowa jakość przestrzeni, Rozprawy Naukowe Instytutu Geografii i Rozwoju Regionalnego, t. 4, Wrocław, s. 69-74.

Dorocki S., Jenner B., 2009, Wpływ wielkości nakładów inwestycyjnych $w$ sektorze $B+R$ na regionalne zróżnicowanie tempa rozwoju Francji, [w:] Rola przedsiębiorczości w ksztaltowaniu społeczeństwa informacyjnego, red. Z. Zioło, T. Rachwał, Zakład Przedsiębiorczości i Gospodarki Przestrzennej Instytutu Geografii Akademii Pedagogicznej w Krakowie, Wydawnictwo Nowa Era, Kraków-Warszawa, s. 188-197.

Euronews, 2010, nr 31, Wptyw kryzysu gospodarczego na zatrudnienie, Warszawa, 30.04.

Fallon P.R., Lucas R.E.B., 2002, The Impact of Financial Crises on Labor Markets, Household Incomes, and Poverty: A Review of Evidence, World Bank Research Observer, Oxford University Press, 17, 1, p. 21-45.

Fernandez de Guevara Radoselovics J., Maudos Villarroya J., 2010, Financial Crisis, Financial Integration and Economic Growth, Working Papers, 20108, Fundación BBVA / BBVA Foundation.

Harold J., 2009, The Crisis of Consumerism, http://www.project-syndicate.org/commentary/james34/ English.

Hospers G.J., 2003, Beyond the Blue Banana? Structural Change in Europe's Geo-Economy, Intereconomics: Review of European Economic Policy, vol. 38, issue 2, s. 76-85.

Komisja Eurpejska, 2009, Employment in Europe 2009, listopad, Bruksela.

Mansoor D., Jalal A., 2011, The Global Business Crisis and Consumer Behavior: Kingdom of Bahrain as a Case Study, International Journal of Business and Management, vol. 6, No. 1; January, s. $104-115$.

Marelli E., Signorelli M., Tyrowicz J., 2010, Crises and Joint Employment Productivity Dynamics: A Comparative Perspective for European Countries, Working Papers, No. 14/2010 (37), Uniwersytet Warszawski, Wydział Nauk Ekonomicznych.

Nistorescu T., Ploscaru C., 2010, Impact of economic and financial crisis in the construction industry, Management and Marketing Journal, vol. VIII, issue 1, s. 25-36.

Pandelica A., Pandelica I., 2009, Consumers' reaction and organizational response in crisis context, Annals of Faculty of Economics, vol. 4, issue 1, s. 779-782.

Perugini C. and Signorelli M. (2007), Labour Market Performance Differentials and Dynamics in EU-15 Countries and Regions, The European Journal of Comparative Economics, No. 2, s. 209-262. 


\section{The impact of economic crisis on transformation of regional structures in France}

It is recognized that the financial crisis, which was the symbolic beginning of the bankruptcy of Lehman Brothers in September 2008, first hit the most advanced countries. A common phenomenon in European countries has become a trend reversal in the labour market, manifesting a decrease in the number of employees. The decline in employment was almost two times higher in developed countries than in developing countries. In developing countries the crisis hit the hardest into export-oriented industries, while in developed countries, into manufacturing industries and trade. Dismissals in building industry relate to a similar extent to different regions of developed countries and developing countries. Economists note that the economic crisis and the differences in pace of its impact on the economy of individual units reduced in recent years the gap between rich regions and those lagging behind.

The study was an attempt to present regional differences in the impact of financial crisis of economy in France on the basis of data characterizing the change in general employment and industry, services and trade. The particular attention was directed to the relationship between the extent of the impact of the crisis on employment size and the degree of economic development.

\section{Dr Sławomir Dorocki}

Uniwersytet Pedagogiczny, Kraków

Instytut Geografii

Zakład Przedsiębiorczości i Gospodarki Przestrzennej

e-mailsdorocki@gmail.com 